\section{Successful endoscopic mucosal resection of Barrett mucosa with high-grade dysplasia in a patient with scleroderma}

Scleroderma is a multisystem disease characterized by fibrosis of skin and internal organs. In $70-90 \%$ of patients, the gastrointestinal tract is involved, and almost $80 \%$ of these patients have dysphagia owing to dysmotility and reflux [1]. Aperistalsis and insufficiency of the lower esophageal sphincter lead to reflux and poor acid clearance. The prevalence of Barrett metaplasia in scleroderma is 2$3 \%$, and the risk of development of adenocarcinoma is estimated to be $0.5 \%$ [2]. Endoscopic techniques such as mucosectomy, radiofrequency ablation, photodynamic therapy, and cryoablation are new alternatives to surgical treatment of high-grade dysplasia or early cancer in Barrett esophagus [3]. Because of the often present aperistalsis, it could be assumed that the formation of esophageal scar tissue in patients with scleroderma who are treated with these techniques could lead to aggravation of dysphagia.

Here we report a case of a patient with scleroderma who underwent mucosectomy for high-grade dysplasia of Barrett mucosa ( Fig. 1). Using the cap technique (Olympus, Hamburg, Germany), a $5 \mathrm{~cm} \times 4.4 \mathrm{~cm}$ large mucosal resection was carried out $3 \mathrm{~cm}$ above the upper end of the gastric folds. Histological examination showed complete resection of the high-grade dysplasia. The resected area was replaced by squamous epithelium without formation of a scar. Surveillance biopsies revealed the presence of a small area of Barrett mucosa with

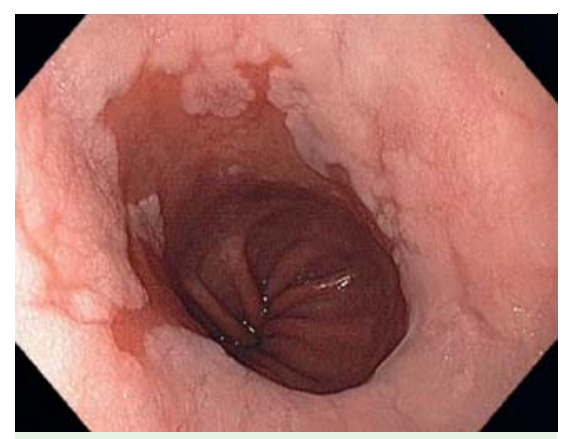

Fig. 1 Barrett mucosa with high-grade dysplasia before intervention.

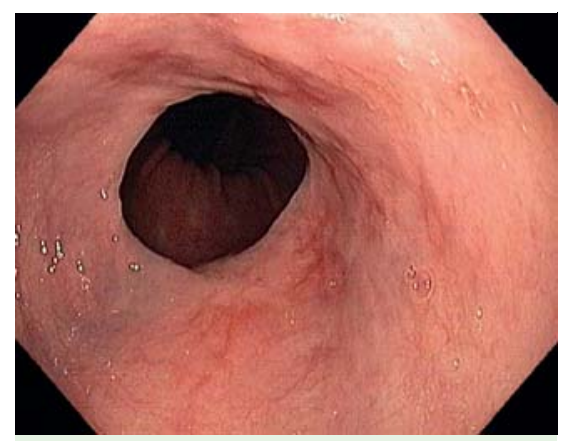

Fig. 2 After mucosectomy and focal radiofrequency ablation.

low-grade dysplasia above the z-line, which was successfully eradicated by focal radiofrequency ablation (BARRX Halo90, Admedics, Zuchwil, Switzerland) ( $\bullet$ Fig. 2). The patient's swallowing function remains stable up to date.

Endoscopy_UCTN_Code_TTT_1AO_2AG

\section{H. Heinrich, P. Bauerfeind}

Klinik für Gastroenterologie und Hepatologie, Departement Innere Medizin, Zürich

\section{References}

1 Ebert EC. Esophageal disease in scleroderma. J Clin Gastroenterol 2006; 40: 769-775

2 Wipff J, Allanore Y. Barrett's oesophagus in systemic sclerosis. Aliment Pharmacol Ther 2007; 25: 857; author reply 858-859

3 Schembre DB, Huang JL, Lin OS et al. Treatment of Barrett's esophagus with early neoplasia: a comparison of endoscopic therapy and esophagectomy. Gastrointest Endosc 2008; 67: 595-601

\section{Bibliography}

DOI $10.1055 / \mathrm{s}-0029-1214664$

Endoscopy 2009; 41: E133

(c) Georg Thieme Verlag KG Stuttgart . New York . ISSN 0013-726X

\section{Corresponding author}

\section{P. Bauerfeind}

Klinik für Gastroenterologie und Hepatologie Rämistraße 100

8091 Zürich

Switzerland

Fax: +41-442554474

peter.bauerfeind@usz.ch

Please notice, that the two pictures were changed on the $10^{\text {th }}$ of September 2009. 